\title{
Vene ja eesti üliõpilaste valikud täis- ja osasihitise kasutamisel
}

\author{
RAILI POOL \\ Tartu Ülikool
}

Ülevaade. Artiklis vaadeldakse L2-kõnelejate sihitisekasutust L1-kõnelejate analoogilise keelematerjali taustal. Analüüsitavaks keeleaineseks on valikvastustega ülesande ning vigade leidmise ja parandamise ülesande vastused. Õppijate introspektsiooni teel kogutud andmed näitavad, et vaadeldav L2-kõnelejatest informandirühm toetub sihitiskäände valikul kõige enam lause põhiverbi vormilistele ja sisulistele omadustele. Sellest infost lähtuvalt on artiklis käsitlemiseks valitud need testülesannete laused, milles verbile toetumine on ootuspärane. L1-kõnelejatest informandid on uurimuse kontrollgrupiks, kelle vastustega õppijate valikuid võrreldakse. Analüüsitav keeleaines näitab, et vaatamata õppijate metalingvistilistele teadmistele objektikasutuse kohta (eriti ilmne on verbile toetumise strateegia), ei vasta nende täis- ja osasihitise kasutus enamikul juhtudel täielikult emakeelekõnelejate omale. Erinevused tulevad esile nii täis- kui ka osasihitist eeldavates kontekstides. Kahe rühma objektikasutus oli sarnane valikvastustega ülesande eitavates lausetes ning mõnede partitiivverbide puhul.

Võtmesõnad: keeleõpe; teise keele omandamine; emakeelekõneleja; teise keele kõneleja; objektikäänded; aspektverbid; partitiivverbid; introspektsioon; vene keel; eesti keel 


\section{Sissejuhatuseks}

Keeleõppe eesmärgiks on anda õppijatele eelkõige teises keeles toimetulemiseks vajalik suhtluspädevus, mitte püüda neist vormida emakeelekõnelejaid. Samas pakub teise keele omandamise uurijatele jätkuvalt huvi küsimus, kas õppijad on üleüldse võimelised emakeelekõnelejate taset saavutama ning millised õpitava keele nüansid on need, mis eristavad edasijõudnud keeleõppijate keelekasutust emakeelekõnelejate omast. Siinkohal on silmas peetud täiskasvanud keeleõppijaid, laste teise keele omandamise eripära selles artiklis ei käsitleta.

Teise keele omandamise uurimise algaastatel sai tuntuks Larry Selinkeri (1972) hinnang, mille kohaselt suudab umbes 5\% keeleõppijaid saavutada õpitavas keeles emakeelekõnelejate taseme. Uurimissuuna arenedes on see hinnang muutunud ning ZhaoHong Hani andmetel ei pea Selinker praeguseks võimalikuks, et täiskasvanud keeleõppijad võiksid saavutada emakeelekõnelejate pädevuse kõigil sihtkeele tasanditel (Han 2003: 98; 2004: 216). Ka Robert Bley-Vroman (1990: 7) ei pea täieliku emakeelekõnelejate kompetentsi saavutamist täiskasvanud õppijate puhul võimalikuks, kuigi mõnede õppijate kõnesooritusi võib olla raske emakeelekõnelejate omast eristada. Niisugune olukord on Bley-Vromani hinnangul kooskõlas tema poolt püstitatud fundamentaalsete erinevuste hüpoteesiga, mis põhineb lapsekeele arenemise ja täiskasvanute võõrkeeleõppe erinevuste kirjeldamisel (Bley-Vroman 1989: 50-51). Väga hea võõrkeeleoskuse mõõtmiseks ja emakeelekõnelejate keelepädevusega võrdlemiseks pole alati ka lihtne sobivaid vahendeid leida. Kenneth Hyltenstam ja Niclas Abrahamsson (2000; Abrahamsson \& Hyltenstam 2009) kinnitavad, et teise keele kõnelejad, kes igapäevases keskkonnas tunduvad emakeelekõnelejatena, erinevad viimastest siiski oma keelekasutuse poolest, kui keeleoskuse üle ei otsustata pelgalt subjektiivse taju järgi, vaid seda analüüsitakse lingvistiliste vahenditega.

Teise keele omandamise alastes uurimustes on emakeelekõnelejatel täita oluline roll: neid kasutatakse kontrollgrupina, hindajatena ning vähemal määral ka katseisikutena (Han 2004: 182-183). Usha Laksh- 
manan ja Larry Selinker peavad õppijate poolt kasutatud sihtkeele variandi e vahekeele (nimetatakse ka õppijakeeleks) süstemaatilist võrdlemist L1-kõnelejate andmetega väga oluliseks. Kui L1 ja L2 kõnesooritused on sarnased, ei saa nende hinnangul L2 sooritust kõrvalekaldeliseks lugeda isegi juhul, kui see erineb sihtkeele grammatikast (Lakshmanan \& Selinker 2001: 398-399). Just tõsiasi, et ka emakeelekõnelejad ise ei pruugi alati saavutada sajaprotsendilist grammatilist korrektsust, on taustaks teise keele uurimises juurdunud seisukohale, mille järgi on õppija keele mingi struktuuri omandanud, kui selle sihtkeelepärase korrektsuse protsent on 90 või suurem (Ellis \& Barkhuizen 2005: 84-85). Emakeelekõnelejatele teise keele omandamise alastes uurimustes kõiketeadva rolli omistamist on ka kritiseeritud (nt Firth \& Wagner 1997), kuid L1 võrdlusmaterjali kasutamine on õppijakeele uuringutes siiski väga levinud. Põhjuseid selleks on siinkirjutaja hinnangul mitu: 1) L1 andmed võimaldavad kindlaks teha õppijakeeles esinevaid kõrvalekaldeid, seejuures õppijate keelekasutust üle- või alahindamata (õppijatelt ei saa nõuda täielikku korrektsust juhtudel, kus ka L1-kõnelejad reeglite vastu eksivad, samas ei saa aktsepteerida õppija keelelist valikut, mille emakeelekõnelejad on täielikult välistanud);2) L1 andmed võimaldavad teha järeldusi ka emakeelekõnelejate endi keelekasutuse ja selles toimuvate muutuste kohta.

Eesti keele täis- ja osasihitise kasutamist on traditsiooniliselt peetud mitte-eestlaste jaoks väga keeruliseks grammatikaosaks, mida on peaaegu võimatu ära õppida emakeelekõnelejate tasemel. Nüüdseks on avaldatud küllalt palju uurimusi, mis kinnitavad sihitisevigade rohkust vene emakeelega üliõpilastel. Nii on Raili Pooli ja Elle Vaimanni esitatud vene üliõpilaste keelevigade sagedusjärjestuses sihitisevead esinemissageduselt kolmandal kohal (Pool \& Vaimann 2005: 133), Anna Verschiku (2004) kogutud materjalis on sihitisevead sageduselt teisel kohal ning Ingrid Kralli kogutud ainestikus olid objektivead sagedasimad käändevalikuvead (Krall 2008: 157). Vene üliõpilaste täis- ja osasihitise kasutamise ja omandamise problemaatikat on põhjalikumalt käsitletud mitmes Pooli artiklis (Pool 2006a, 2007a, 2007b), millest 
ilmneb selle grammatikavaldkonna keerukus keeleõppijate jaoks nii nende kõnesoorituste kui ka õppijate introspektsiooni põhjal. Nimetatud uurimustes on õppijakeeles esinevate sihitisevigade määratlemisel lähtutud peamiselt eesti keele grammatika reeglistikust ja uurija enda keeletajust, emakeelekõnelejatelt kogutud võrdlusmaterjali on kasutatud vähe. Seega, kui rääkida sellest, kas keeleõppijad suudavad omandada sihitisekasutuse emakeelekõnelejate tasemel, tuleks uurida ka seda, milline on emakeelekõnelejate tegelik objektitarvitus ja kuidas õppijate sihitisekasutus sarnastes kasutuskontekstides sellest erineb või sellega sarnaneb. Kui õppijakeelt emakeelekõnelejate kõnesoorituste andmetega ei võrrelda, võib tulemuseks olla õppijakeele alahindamine, mille eest hoiatavad Lakshmanan ja Selinker (2001: 399).

Eesti keelt emakeelena kõnelejate täis- ja osasihitise valikuid on katselise meetodiga uurinud Martin Ehala (2009), kelle uurimuse eesmärgiks oli välja selgitada teise keele kõnelejate sihitisekasutuse võimalikud mõjud emakeelekõnelejate objektitarvitusele. Selleks viis ta läbi laiaulatusliku uuringu eesti õppekeelega gümnaasiumide eesti ja vene kodukeelega õpilaste hulgas. Vormimoodustustesti ja tajutesti tulemused näitavad partitiivobjekti ülekasutuse tendentsi nii vene kui ka eesti emakeelega õpilastel, nominatiiv- ja genitiivobjekti ülemäärane kasutus iseloomustab eelkõige vene õpilaste valikuid ning seda esineb eesti noortel vähe (samas). Uuritud on ka sihitisekasutust väliseestlastel, kellel on sarnaselt eesti keele kui teise keele õppijatega täheldatud probleeme eelkõige täissihitise tarvitamisel (Lehiste \& Kitching 1998; Raag 1985). Raskusi täissihitise korrektse kasutamisega ning sellest tulenevat partitiivobjekti ületarvitust on täheldatud ka eesti-inglise kakskeelsete laste eesti keeles (Torn 2004). Reili Argus (2009) on psühholingvistilise katse abil uurinud objekti käändevahelduse omandamist eesti lapsekeeles ning tema katse tulemused näitavad, et perfektiivsuse ja genitiivi seos on eesti lastel viieaastaselt selge, kuid imperfektiivsuse ja partitiivi seoste omandamine vajab lisauuringuid.

Käesolevas artiklis tulevad vaatluse alla edasijõudnud eesti keele õppijate täis- ja osasihitise valikud emakeelekõnelejate analoogilise 
keeleainese taustal. Selleks kirjeldatakse ühe konkreetse eesti keelt teise keelena kõneleva informandirühma sihitisekasutust uurimuslikel eesmärkidel koostatud testülesandes sisaldunud üksiklausete kaudu. Sama ülesande sooritanud L1-kõnelejad on katse kontrollgrupp, kelle vastustega õppijate tulemusi võrreldakse. Õppijakeele analüüsimisel rakendatakse lingvistilist lähenemisviisi. Täis- ja osasihitise kasutamine lauses sõltub erinevatest faktoritest (nt objekteseme määratus või määramatus, sihitise põhjaks oleva öeldisverbi vorm ja semantika, lause struktuur jm), mida kõike pole võimalik ühes kirjutises võrdselt arvesse võtta. Artiklis keskendutakse kitsamalt lause põhiverbist lähtuvale sihitiskäände valikule. Sellise valikuprintsiibi taga on vaadeldavalt informandirühmalt kogutud introspektiivsed andmed. Artikli eesmärgid on järgmised: a) kirjeldada õppijate sisendkeelde kuuluvat grammatilist taustainfot lause põhiverbi rollist täis- ja osasihitise vormi määramisel ning tutvustada õppijate endi arusaamu sihitiskäänete kasutamise ja lause põhiverbi seoste kohta; b) jälgida konkreetsete testilausete kaudu, kuidas õppijate metalingvistilised teadmised tegelikus täis- ja osasihitise kasutamise situatsioonis realiseeruvad ning kas ja millistel juhtudel on õppijate valikud võrdväärsed emakeelekõnelejate vastavate valikutega.

\section{Artiklis käsitletava uurimuse taustast}

\subsection{Materjal ja informandid}

Artiklis analüüsitav keeleaines pärineb eesti keele täis- ja osasihitise kasutuse uurimiseks koostatud objektitestist. Test koosneb kolmest osast: valikvastustega ülesanne, vigade leidmise ja parandamise ülesanne ning tõlkeülesanne. Siinses artiklis käsitletakse neist ainult kaht esimest kuna eesti informandid venekeelseid lauseid eesti keelde ei tõlkinud, pole võimalik tõlkeülesande vastuseid võrrelda. Valikvastustega ülesandest ja vigade leidmise ja parandamise ülesandest on artiklis käsitlemiseks valitud need laused, mille puhul on sihitiskäände valik tugevasti seotud lause põhiverbi vormi ja semantikaga. Mõningaid objektitestis sisaldu- 
nud lauseid on käsitletud artikli autori varasemates publikatsioonides (Pool 2007a, 2007b), kuid testülesandeid põhjalikumalt pole varem analüüsitud. Artiklis tuuakse esile ka informantide endi arvamusi, millest nad eesti keele sihitise kasutamisel lähtuvad. Introspektiivne materjal on kogutud samadelt informantidelt, kes sooritasid ka testülesanded, küsitlus on läbi viidud suuliselt 2004. aastal (samade õppijate arvamusi konkreetsetesse lausetesse sobivast sihitise vormist vt Pool 2006a).

Teise keele kõnelejatest informantideks on 29 Tartu ülikooli eesti keele (võõrkeelena) eriala vene emakeelega üliõpilast, kes testi läbiviimise ajal (2004. a) valdasid tol ajahetkel Eestis kasutusel olnud tasemeeksamite süsteemi kohaselt eesti keelt kõrgtasemel. ${ }^{1}$ Praeguseks on keeleoskustasemete süsteemi muudetud ning endine kõrgtase on võrreldav keeleoskustasemega C1. Muudest kõrgtasemel eesti keelt valdavatest mitte-eestlastest eristub vaadeldav informandigrupp selle poolest, et eesti filoloogia viimase aasta üliõpilastena on nad lisaks praktilistele keelekursustele saanud ka süsteemse tänapäeva eesti keele grammatika alase hariduse. Täis- ja osasihitise problemaatika õppimisel on ülikoolis olnud aluseks eesti keele teaduslik grammatika (EKG 1993: 46-53), informandid oskavad sihitist muudest lauseliikmetest eristada ning tunnevad vähemalt teoreetiliselt grammatilise objekti olemust ja kasutustingimusi. Informantide oskust sihitise käände valikut eksplitsiitselt põhjendada kinnitavad neilt introspektsiooni teel kogutud andmed, mis annavad tunnistust ka sellest, et grammatikareeglite tundmine ei vii iga kord siiski sihtkeelepärase valikuni (vt Pool 2006a)2 .

Emakeelekõnelejatest informantideks on 30 Tartu ja Tallinna kõrgkoolide erinevate erialade üliõpilast, valdavalt mittefiloloogid.

\footnotetext{
Uurimusse on kaasatud maksimaalne hulk kirjeldatud rühma kuuluvaid informante. Kuna rohkem kõrgtaseme eksami edukalt sooritanud eesti keele (võõrkeelena) eriala viimase aasta üliõpilasi testi läbiviimise perioodil ei olnud, polnud võimalik rohkem informante kaasa haarata.

2 Oluline on märkida, et kõik käesolevas artiklis esitatavad tulemused ja järeldused käivad vaid selle õppijarühma kohta ning ei ole üldistatavad muudele eesti keelt teise keelena kõnelejatele.
} 


\subsection{Lause põhiverbist lähtuv sihitisekäsitlus L2-kõnelejatest informantide sisendkeeles}

Eesti keele eriala üliõpilastena on siinse uurimuse vene emakeelega informandid õppinud täis- ja osasihitise kasutuskriteeriume teoreetiliselt eesti keele lauseõpetuse kursusel ning rohkete praktiliste keeleharjutustega erinevate õppeainete raames. Lisaks on nad kogu stuudiumi vältel saanud õppejõududelt oma eestikeelsete kirjalike tööde kohta korrektset tagasisidet, mis hõlmab ka sihitisevigade analüüsi. Teoreetiliseks taustaks on ülikooliõppes olnud eesti keele teadusliku grammatika sihitisekäsitlus (EKG 1993: 46-53), milles lähtutakse objekti käändevariandi põhjendamisel nii situatsiooni kui ka objektieseme piiritletusest või piiritlematusest, liigitatakse transitiivverbid kolmekäändelist objekti võimaldavateks aspekt- ja ainult partitiivobjekti liitvateks partitiivverbideks, käsitletakse eraldi täissihitise käände valiku põhimõtteid ning erandliku vormivariandiga sihitisi. Informantidele oli seega sisendkeele kaudu kättesaadav eesti keele sihitisekäsitlus kogu oma detailirikkuses. Teise keele omandamise alastes uurimustes on tavaks liigitada sisendkeeles sisalduvat keelematerjali positiivseks ja negatiivseks. Positiivse materjali hulka arvatakse korrektsed laused ja mudelid, mis on õppijale suulisest või kirjalikust keelest kättesaadavad, negatiivse materjaliga puutub õppija kokku keeleliste kõrvalekallete puhul ning sellistel juhtudel võib olla tegemist nii õppija vea eksplitsiitse parandamise kui ka vihjamisi antud infoga keelendi ebasobivusest (Gass 2005: 225-226). Sihitise vormivaliku omandamisel oli käesoleva uurimuse informantidele pikema perioodi jooksul kättesaadav nii positiivne kui ka negatiivne sisendkeele materjal. Teise keele omandajad ei suuda siiski kunagi kogu sisendkeele ainest produktiivselt kasutama õppida. Õppijad ilmselt ei mõista sisendkeelest kõike ja sellest osast, millest nad aru saavad, võtavad kasutusele vaid osa, millest üht osa teadvustavad ning teist osa valdavad implitsiitselt (Siitonen 1999: 26). Eesti keele sihitise kogu reeglistik on paljude jaoks liiga nüansirohke, mistõttu õppijad kipuvad tegema enda jaoks arusaadavamaid üldistusi. Üldistamine ja lihtsustamine on seejuures käsitletav 
õppija strateegiana (Ellis 1990: 171-172). Siinne artikkel keskendub lause põhiverbi vormile ja semantikale, kuna vaadeldavad informandid püüavad sihitise käände valikul toetuda peamiselt verbile ja otsivad tuge verbi vormilistest ja semantilistest omadustest.

Oppijate jaoks lihtsaim verbist lähtuv sihitisekasutust puudutav reegel käsitleb eitava verbivormi ja partitiivobjekti seost ning sellekohased keeleteadmised peaks kõrgtasemel õppijatel olema juba omandatud. Õppijatele on sisendkeelest tuttav ka nominatiivse täissihitise seos impersonaalse ja imperatiivse öeldisverbiga ning neile on tutvustatud ka da-infinitiivi laiendavate objektide vormivalikut. Õppijad toetuvad seejuures verbivormile sageli liiga tugevasti, arvates, et impersonaalse ja imperatiivse öeldisverbi juurde kuulub alati nominatiivne objekt, kuigi ka neil juhtudel tuleb arvestada osasihitise võimalusega (Pool 2006a).

Eesti keele kui teise keele õppes on tavaks rõhutada aspekt- ja partitiivverbide erinevust, kusjuures partitiivverbid soovitatakse enamasti lihtsalt ära óppida - kui need verbid on teada, pole õppijatel tarvis sihitise käändevaliku peale täiendavalt mõelda. Ka siinse uurimuse informantide eesti keele õpe pole selles osas erand. Probleemiks on siin jällegi keeleainese suur maht ja detailirohkus: tavalisemate partitiivverbide (nt armastama, nägema jt) äraõppimine ei valmista õppijatele enamasti raskusi, kuid kõiki ära õppida ei jõua ilmselt keegi. Asja teeb keerulisemaks ka see, et paljudel juhtudel eeldab partitiivverbile resultatiivse laiendi lisamine ka sihitise käände muutmist (nt ootama keda?, aga ootab kelle ära). Käesoleva artikli vene emakeelega informantidele on eesti keele õpetamise käigus tutvustatud lisaks transitiivverbide traditsioonilisele jaotusele aspekt- ja partitiivverbideks ka võimalust jagada partitiivverbid kaheks vastavalt sellele, kas neile saab lisada resultatiivseid laiendeid ja sellega seoses on võimalik ka täissihitis, või mitte (Rätsep 1978: 221-224; Klaas 1999). Siinkirjutaja õpetamiskogemus näitab, et õppijatel pole lihtne aru saada, millised verbid ja mis kontekstis resultatiivseid laiendeid liidavad ning seesuguste konstruktsioonide produtseerima õppimine nõuab pikaajalist harjutamist. 
Siin käsitletud taustainfo on oluline järgnevalt vaatluse alla tulevate õppijate endi arusaamade ning objektitesti tulemuste analüüsimisel, võimaldades informantide täis- ja osasihitise valikuid paremini mõista.

\subsection{Vene emakeelega informantide arusaamad verbi rollist sihitise käände kasutamisel}

Õppijate introspektsioon võimaldab keeleuurijatel pääseda lähemale õppijate produtseerimisprotsessi etappidele ning selle käigus tehtavate keeleliste valikute põhjustele, andes väärtuslikku teavet selle kohta, millisena teise keele kõneleja ise oma keelekasutust kogeb ja milliseid seaduspärasusi enda jaoks loob. Siinse uurimuse informantidelt on kogutud introspektiivne materjal täis- ja osasihitise kasutamise teemal. Informantidele esitati seitse eestikeelset lauset, milles paluti kasutada sihitist nende arvates sobivas käändes ning oma valikut põhjendada. Seda ainestikku on juba põhjalikumalt käsitletud eraldi artiklis (Pool 2006a), mistõttu siin konkreetsete lausete objektivaliku põhjendustel enam ei peatuta. Järgnevalt vaadeldakse introspektiivse ainestiku üldist osa, milles paluti informantidel lühidalt kokku võtta, millistest kriteeriumidest nad sihitise vormivalikul tavaliselt lähtuvad. Introspektiivne materjal on kogutud 15 informandilt, kes kuulusid ka objektitesti sooritanud üliõpilaste gruppi. ${ }^{3}$

Mitu üliõpilast tõid sihitisekasutuse peamise toetuspunktina üldiselt esile verbi:

R.P.: kui sa pead seda objekti kasutama siis mille järgi sa tavaliselt valid?

INF A: kõigepealt ma vaatan verbi

Verbi juures toodi esile erinevaid aspekte, näiteks verbivormi üldiselt:

INF B: verbivorm on ikka see peamine

Näidetes on küsitleja tähistatud lühendiga R.P., eri informantide arvamused on eristatud tähtedega, nt INF A, INF B jne. Märgend (.) tähistab lühikest ja (...) pikemat pausi. 
Verbivormist lähtuval põhjendamisel toodi esile ka eituse olulisust:

INF C: no kõigepealt ma vaatan verbile ikka (.) et mis tegevus on ja siis võib-olla arv (.) noh verb selle all ma mõtlen ka eitust

Informantidelt küsiti ka arvamust selle kohta, kas nende hinnangul võivad õppijad impersonaalse öeldisverbi puhul lähtuda sihitiskäände kasutamisel primaarselt verbi umbisikulisest vormist, valides just seetõttu nominatiivse sihitise. Selline arvamus leidis kinnitust:

R.P.: mul on jäänud mulje et vene õpilastega tuleb kuskilt koolist kaasa et kui on umbisikuline tegumood siis on nominatiiv

INF D: jaa (.) alati tuubitakse pähe et umbisikuline tegumood siis on nominatiiv (.) ja sellepärast ma praegu kahtlesin kas nimetav või osastav

Sama arvamuse kinnituseks viidati ka eestikeelsest grammatikakirjandusest tuttavale lingvistilisele infole, mis näitab sisendkeelest tuttava materjali eksplitsiitset valdamist:

R.P.: et kas see on sinu meelest keeleõppijate seas laialt levinud arvamus (.) et kui verb on umbisikuline siis peab olema nominatiiv?

INF E: jah

R.P.: kust see arvamus on pärit (.) kas keeleõpetajad on seda õpetanud?

INF E: jah (.) mind õpetati (.) eesti keele käsiraamatus on ka öeldud et kui alust ei ole siis objekt on nagu nominatiivis (.) nagu asendab seda alust (...) aga peab vaatama ka kas on partitiiviverb

Üheks verbi juures oluliseks peetud teguriks osutus ka verbi ajavorm, toodi esile nii konkreetselt minevikuvormi olulisust tegevuse lõpetatuse tähistajana kui ka ajavorme üldiselt, nende seost sihitiskäänetega täpsustamata:

R.P.: mille järgi sa tavaliselt teed selle valiku?

INF F: mina vaatan aega (...) kas on minevik, olevik või tulevik (...) siis ma vaatan kas on terve objekt või osa

Verbi puhul peetakse oluliseks ka seda, kas see väljendab lõpetatud või lõpetamata tegevust: 
R.P.: mille järgi sa seda valikut teed enamasti?

INF G: ee: (...) ikka lõpetatud või lõpetamata tegevus (...) ja ka see (.) partitiiviverbid ka

Artikli alajaotises 2.2 kirjeldatud taustainfo, mille kohaselt on informantidele sisendkeelest tuttav transitiivverbide liigitus partitiiv- ja aspektverbideks, sai õppijate küsitluses kinnituse, mitmed märkisid sihitise vormivaliku kriteeriumina verbi kuulumist partitiivverbide hulka. Samas toodi esile probleemi, et alati ei teata, mis on partitiivverb ja mis mitte:

R.P.: aga kas see verbide jaotumine partitiiviverbideks ja nendeks muudeks mis ei ole partitiiviverbid (.) kas see aitab sind?

INF H: mõnikord aitab aga mõnikord ei tea mis on partitiiviverb (.) kui ma koolis õppisin (.) palusin eestlasi seletada (.) aga nad ei oska (.) nendel vist on see intuitsioon

Lisaks partitiivi nõudvatele verbidele toodi esile ka verbe, mis informandi teadmistes on kinnistunud genitiivi nõudvatena:

R.P.: mille järgi sa tavaliselt otsustad?

INF I: kõigepealt verb ja

R.P.: mis sa selle verbi juures vaatad? kas seda partitiiviverbi?

INF I: kas on lõpetatud ja (.) need verbid nagu andma ja võtma ja leidma nõuavad ikka genitiivi

Õppijate introspektsiooni põhjal võib tõdeda, et vaadeldavale informandirühmale on sihitise kasutamisel kõige olulisem lauses sisalduv verb, mille puhul toetutakse nii vormilisele (eitus, umbisikuline tegumood, ajavorm) kui ka tähenduslikule küljele (partitiivi või genitiivi nõudvad verbid), ning püütakse selgusele jõuda, kas tegevus on lõpetatud või mitte. Objekteseme enda omadustest lähtumist toodi esile harva, vaid üksikutel juhtudel räägiti osa ja terviku suhetest. Lause põhiverbile toetumist ja sellest lähtumist võib pidada vaadeldavate informantide strateegiaks sihitise kasutamisel ning järgnevas analüüsis on vaatluse alla võetud need objektitesti laused, mille puhul sihitise vormivalik seondub tugevasti just verbiga. 


\section{L2- ja L1-kõnelejate valikud täis- ja osasihitise kasutamisel}

\subsection{Valikvastustega ülesanne}

Objektitesti esimeses ülesandes esitati informantidele üksiklaused, milles sihitise kohad olid tähistatud punktiiriga. Iga lause juures oli antud keelelisest kontekstist lähtuvalt kaks või kolm sihitiskäände varianti, mis olid tähistatud tähtedega A, B ja C. Niisuguste valikuvariantide ette andmisega on püütud välistada analüüsi takistavaid morfoloogiavigu, mis võinuksid esineda L2-kõnelejate testides, kui nad oleksid ise pidanud vajalikud käändevormid moodustama. Informantidel paluti lausetes olevatesse lünkadesse kirjutada nende arvates sinna kõige paremini sobiva sihitisevariandi ees olev täht; kui sobivana tundus mitu valikuvarianti, võis lisada need kõik. Kuna analüüsi aluseks on õppijate jaoks oluline verb, on laused liigitatud selle järgi, kas sihitise põhisõnaks olev verb kuulub aspekt- või partitiivverbide hulka, tähelepanu pööratakse ka verbi vormilistele omadustele (eitus, umbisikuline tegumood). Vene emakeelega informantide vastused on tähistatud sõnaga vene, eesti grupi vastused sõnaga eesti.

\subsubsection{Sihitis aspektverbi laiendina}

(1) Inimeste arvates garanteerib kõrgharidus neile A hea töökoht ja palk $\mathbf{B}$ hea töökoha ja palga $\mathbf{C}$ head töökohta ja palka vene: $\mathrm{A} 1(3,4 \%) \quad$ B $4(13,8 \%) \quad$ C $24(82,8 \%)$ eesti: A $0 \quad$ B $30(100 \%) \quad$ C 0

(2) Mari jõudis eksamile õigeks ajaks, sest isa tõi autoga kooli ukse ette.
A ta (kelle?)
B tema (kelle?)
C teda
vene: A $11(38 \%)$ B $3(10,3 \%)$
C $12(41,4 \%)$
A/B $3(10,3 \%)$
eesti: A $27(90 \%)$ B 0
$\mathrm{C} 0$
A/(B) $3(10 \%)$ 
(3) Loodan, et mulle antakse veel oma töö tegemiseks.
A teine võimalus
B teise võimaluse
C teist võimalust
vene: A $18(62,1 \%)$
B $6(20,7 \%)$
C $5(17,2 \%)$
eesti: A $30(100 \%)$
B 0
$\mathrm{C} 0$

Lausetes (1) ja (2) laiendab sihitis isikulises tegumoes aspektverbe ning mõlemal juhul on tegemist genitiivset täissihitist eeldava kontekstiga, mida näitab ka eesti grupi ühtlane tulemus. Lauses (1) sisalduv öeldisverb garanteerima võiks kuuluda nende väheste transitiivverbide hulka, mis tähenduselt perfektiivsetena liidavad endaga enamasti täissihitise. Niisuguste verbidena on nimetatud ka ammendama, andestama, kaotama, lõpetama, saavutama (Metslang jt 2003: 127). Enamus vene rühmast on pidanud sobivaks siiski partitiivobjekti, mis näitab, et vaadeldavad keeleõppijad lauset (1) perfektiivsena ei taju, vaid tõlgendavad seda pigem protsessina, lähtuvad verbi oleviku ajavormist (täissihitisega seostatakse peamiselt minevikku) või ei pea täissihitist lause sisu arvestades reaalseks ${ }^{4}$. Õppijad jätavad kasutamata võimaluse toetuda sihitise põhjaks oleva verbi sisulisele resultatiivsusele. Lause (2) objektnoomeniks on valitud lühikese ja pika kujuvaheldusega personaalpronoomen tema/ta ning valikuteks antud lühike ja pikk genitiivivorm ning partitiiv. Selle lause eesmärgiks oli täis- ja osasihitise valiku kõrval testida ka lühikese ja pika pronoomenikuju valikuid, nominatiivivormid kui genitiivikujudega vormihomonüümia tõttu identsed on liigse detailsuse tõttu välja jäetud. Varasemates uurimustes on täheldatud keeleõppijate kalduvust pikki pronoomenikujusid üle tarvitada (Pool \& Vaimann 2005: 125) ning primaarselt nominatiivivormina esinevat lühikuju ta võib teise keele kõnelejatel olla üldse raske genitiivina tajuda. Siinsed tulemused näitavad, et pikka genitiivset pronoomenikuju ei eelista kumbki informandirühm ning õppijate metalingvistilistest teadmistest annab märku asjaolu, et kolmandik on valinud emakeelekõnelejatega sarnaselt lühikese genitiivi-

\footnotetext{
$4 \quad$ Viimase tõlgenduse pakkus välja üks informantidest, kelle arvates ei pruugi vene noored pidada kõrgharidust hea töökoha ja palga eelduseks, mistõttu täissihitist ei peeta sobivaks ja valitakse partitiivobjekt.
} 
vormi. Täissihitise valimist toetab sihitise põhjaks oleva verbi tõi minevikuvorm, mis annab õppijatele märku tegevuse lõpetatusest.

Umbisikulises tegumoes aspektverbe laiendavate sihitiste käändevalikut illustreerivas lauses (3) on tegemist täissihitist eeldava kontekstiga. Õppijate introspektsioon näitab, et umbisikulist verbivormi seostatakse peamiselt nominatiivse objektiga. Verbi vormile toetumine võibki olla õppijarühma rohke nominatiivi valiku taga, mis konkreetsel juhul on osutunud ka grammatiliselt korrektseks variandiks ning eesti rühma ainukeseks valikuks. Genitiivi ja partitiivi kasutus õppijate rühmas näitab, et mitte kõik kõrgtasemel teise keele kõnelejad ei lähtu siin ainult verbi umbisikulisusest, eriti genitiivi kui primaarse täissihitise käände valinud on lähtunud ilmselt tegevuse lõpule jõudmise võimalusest, mitte pelgalt verbi morfoloogilisest vormist.

Õppijatel esines kõigis lausetes emakeelekõnelejatega võrreldes partitiivi ülekasutus, mida võib pidada teise keele kõnelejate sihitisetarvituse iseloomulikuks jooneks. Partitiiv on eesti keeles sihitise põhikääne, mida keeleõppijad sageli üldistavad igasugustes sihitise kasutuskontekstides ${ }^{5}$.

(4) Kas härrasmees ei või võtta õhtul ?...?
A klaasike viskit
B klaasikese viskit $\mathbf{C}$ klaasikest viskit vene: A 0
B $8(27,6 \%)$
C $21(72,4 \%)$
eesti: A $2(6,7 \%) \quad$ B $11(36,7 \%)$
C $13(43,3 \%) \quad$ B/C $4(13,3 \%)$

(5) Mis juhtub, kui ainuke kandidaat direktori kohale ei kogu valimisnõukogus hääli?
A vajalik hulk
B vajaliku hulga
C vajalikku hulka
vene: A $1(3,4 \%)$
B $2(6,9 \%)$
C $26(89,7 \%)$
eesti: A $1(3,3 \%)$
B $3(10 \%)$
C $26(86,7 \%)$

\footnotetext{
5 Partitiivi ülekasutuse taga nähakse sageli ühe põhjusena ka vene akusatiivi ülekandmist eesti keelde partitiivi kujul. Siinses artiklis pole võimalik õppijate emakeele võimalikku mõju ammendavalt käsitleda, mistõttu see problemaatika jääb vaatluse alt välja.
} 
Eitava öeldisverbi juurde kuulub eesti keeles reeglina partsiaalobjekt ning see on teise keele õppijate jaoks lihtsaim sihitise kasutamise reegel, mis kõrgtasemel eesti keele kõnelejatel peaks olema juba omandatud. Käesoleva uurimuse informantide kirjalikest tekstidest kogutud sihitiste analüüs näitab, et see tõepoolest nii on: samade üliõpilaste kirjandites olid eitavat öeldisverbi laiendavad objektid reeglipäraselt partitiivis ning vigu ei esinenud (Pool 2005). Sellest lähtuvalt on objektitesti valitud pisut keerukama struktuuriga eitavad laused, mis võimaldaksid saada infot harvemini esinevate keeleliste kontekstide kohta ning jälgida ka emakeelekõnelejate sihitisekasutuse varieeruvust. Näitega (4) on soovitud testida informantide valikuid eitavavormilise kahtlusküsimuse osas, mille puhul võib eesti keele grammatika kohaselt mõnikord kasutada osasihitise asemel ka täissihitist (EKG 1993: 52). Lause ise pärineb ühe telesarja eestikeelsetest subtiitritest ning selles oli kasutatud genitiivset sihitist. Teise keele kõnelejatelt eeldasin selle lause puhul reeglitest lähtumist ning partitiivobjekti valimist. Lause (4) tulemused varieeruvad mõlema vastajarühma puhul. L2-kõnelejatest oli üllatavalt suur osa valinud siiski ebareeglipäraselt genitiivi, mille taustaks võivad olla nende teoreetilised teadmised eesti keele grammatikast. Seesugune valik ühtlustab tunduvalt õppijate ja emakeelekõnelejate sihitisekasutust, kuna ka eesti rühmast olid ligi pooled valinud täissihitise, sealhulgas kaks vastajat ka nominatiivi. Lauses (5) eesti ja vene rühma valikud praktiliselt ei erine, üksikute eranditega on suurem osa informante valinud sellesse lausesse reeglipärase partitiivobjekti. Lause (5) koostamisel on aluseks võetud ajalehekeelest pärinev näide, milles eitavas lausekonstruktsioonis oli tarvitatud genitiivset objekti vajaliku hulga. Siinse testi tulemused ei näita, et kvantor hulk oleks emakeelekõnelejate keeleteadmistes grammatilistes käänetes üldistunud kujul hulga - eesti rühma informandid on enamuses valinud reeglipärase osasihitise. Õppijate jaoks on eitava verbivormi puhul verbile toetudes partitiivobjekti kasutamine alati kindel valik, mis viib sihtkeelepärase tulemuseni. 
(6) Olga läks raamatukokku kavatsusega lõpetada.
A referaat
B referaadi
C referaati
vene: A $8(27,6 \%)$
B $12(41,4 \%)$
C $9(31 \%)$
eesti: A $29(96,7 \%)$
B 0
C $1(3,3 \%)$

Keeleõppijate jaoks on näites (6) sisalduva $d a$-infinitiivi objekti käändevalik väga keeruline, seda eriti täissihitise käänete kasutuse osas, mis nõuab grammatilisi teadmisi ning lauseanalüüsi oskust. Eesti keeles on $d a$-infinitiivi laiendav täissihitis enamasti nominatiivis, genitiivne totaalobjekt on võimalik vaid juhul, kui $d a$-infinitiiv talitleb ise lauses sihitisena või kuulub koos modaalverbiga liitpredikaadi koosseisu, tähelepanu peab pöörama ka finiitverbi vormile ning semantikale. Näites (6) on da-infinitiiv ise lauses täiendi funktsioonis ning täissihitisena on võimalik ainult nominatiivi kasutamine. Kuna lõpetada-verbi tajutakse sageli lõpetatust väljendavana, pole genitiivi kui täissihitise põhikäände valinute rohkuses midagi üllatavat, pigem annab see tunnistust õppijate eksplitsiitsete keeleteadmiste rakendamisest ning verbi sisulisele küljele toetumisest. Keeleõppijatele iseloomulikuna esineb siin ka partitiivobjekti ületarvitust, eestlaste valikud näitavad, et tegemist on kindlalt täissihitist eeldava kontekstiga.

\subsubsection{Sihitis partitiivverbi laiendina}

(7) Artikkel sisaldab ainult mis eksperimendi käigus saadi. A esialgsed tulemused vene: A $1(3,4 \%)$ B esialgseid tulemusi eesti: A $1(3,3 \%)$ B $28(96,6 \%)$

(8) Ma kuulsin hiljuti mis puudutas just minu uurimisteemat.
A üks huvitav
B ühe huvitava
C üht huvitavat ettekanne ettekande ettekannet vene: A 0 B $13(44,9 \%)$
C $15(51,7 \%)$
B/C $1(3,4 \%)$ eesti: A 0 B 0 C $29(96,7 \%)$
C/(B) $1(3,3 \%)$ 
(9) hinnatakse tööturul kõrgelt.
A head oskustöölised
B häid oskustöölisi
vene: A $4(13,8 \%)$
B $25(86,2 \%)$
eesti: A 0
B $30(100 \%)$

Lausetes (7-9) sisalduvad öeldisverbid liigitatakse tavapäraselt partitiivverbide hulka, mis eesti keele kui võõrkeele õppes soovitatakse enamasti lihtsalt ära õppida. Emakeelekõnelejad ongi valinud ootuspäraselt peamiselt partitiivobjekti, pakkudes üksikjuhtudel ka täissihitise võimalusi. Huvipakkuvad on lause (7) tulemused, mis on L2- ja L1-kõnelejatel sarnased. Lause (7) sisaldama-verbi on tegelikult eesti keeles võimalik kasutada ka koos täissihitisega, seda just täielikkuse toonitamise eesmärgil (Erelt 2000: 93). Seda arvestades on emakeelekõnelejate üsna üksmeelne partitiivi valik (vaid kaks vastajat olid teisel arvamusel, üks valis nominatiivi ning teine jättis valiku tegemata) huvitav ning annab infot eesti rühma keeletaju kohta. Õppijate üksmeelne (ainult ühe erandiga) partitiivi valik selles lauses on tegelikult üllatav, sest sisaldama pole õppematerjalides eriti tavaline ning ei pruugi neile sisendkeelest partitiivverbina tuttav olla. Ühe informandi sõnul võib partitiivi valimise taga olla hoopis õppijate soov vormistada sihitis alusest erinevas käändes. Näidete (8) ja (9) öeldisverbe on informantidele keeleõppes esitatud partitiiviverbidena ning testi tulemused näitavad, mida sisendkeelest vastu on võetud. Lause (9) verbi hindama peab vaadeldav õppijarühm kindlamini partitiiviverbiks kui lause (8) verbi kuulma. Näites (8) genitiivse täissihitise valinud õppijad näitavad sellega oma grammatilisi teadmisi: nominatiivi kui sellesse lausekonstruktsiooni sobimatut ei pakkunud keegi, genitiivi valikul on ilmne informantide soov väljendada sel viisil tegevuse lõpetatust, tuge pakub siinjuures öeldisverbi imperfektivorm. Näites (9) avaldub tüüpiline erinevus eesti ja vene rühma objektikasutuse vahel: umbisikulises tegumoes öeldisverbi juurde valivad mõned keeleõppijad peaaegu alati nominatiivobjekti, kuna seda seostatakse impersonaalse verbivormiga (ja ka käskiva kõneviisiga). 


\subsection{Vigade leidmise ja parandamise ülesanne}

Objektitesti teine ülesanne kuulub oma olemuselt teise keele uurimises laialdaselt kasutatavate grammatilise korrektsuse hindamise testide rubriiki. Niisuguste testide puhul palutakse informantidel otsustada, kas sihtkeelsed laused on nende arvates grammatiliselt korrektsed või mitte, viimasel juhul võidakse paluda ka vea parandamist. Õppijakeele varieeruvuse seisukohast esindavad grammatilise korrektsuse hindamise testide vastused õppijakeele kõige ettevaatlikumat stiili, milles avalduvad eelkõige eksplitsiitsed keeleteadmised ning kõnesooritused võivad vaba stiili esindavast spontaanse keelekasutuse materjalist erineda (Tarone 1983: 152).

Siin analüüsitava objektitesti teises ülesandes paluti informantidel parandada lausetes nende hinnangul sisalduvad vead ning jätta korrektseks hinnatud laused muutmata. Esindatud on valikvastusega ülesandega sarnased sihitise kontekstid. Selguse huvides on järgnevas kokkuvõttes lausetes esinevad sihitised alla joonitud (informantidele antud testides allajoonimisi ei olnud). Kahe ülesande tulemuste parema võrreldavuse huvides jätkatakse siin valikvastustega ülesande lausete numeratsiooni.

\subsubsection{Sihitis aspektverbi laiendina}

(10) Edu rahvusvahelisel konkursil tõstis noore pianisti enesehinnangu.

$\begin{array}{lll}\text { NOM enesehinnang } & \text { GEN enesehinnangu } & \text { PART enesehinnangut } \\ \text { vene: } 1(3,4 \%) & 21(72,5 \%) & 7(24,1 \%) \\ \text { eesti: } 0 & 0 & 30(100 \%)\end{array}$

(11) Kui vahetatakse töökoht, siis kaasneb sellega sageli ka teise linna kolimine.

\begin{tabular}{|c|c|c|c|}
\hline мом töökoht & Nom töökoht + ära & GEN töökoha & PART töökohta \\
\hline vene: $16(55,2 \%)$ & $1(3,4 \%)$ & $1(3,4 \%)$ & $11(38 \%)$ \\
\hline eesti: $4(13,3 \%)$ & 0 & 0 & $26(86,7 \%)$ \\
\hline
\end{tabular}


(12) Ühe väikse vea pärast pole vaja terve töö ümber kirjutada.

\section{NOM / GEN terve töö $\quad$ PART tervet tööd}

vene: $17(58,6 \%)$

eesti: $2(6,7 \%)$
$12(41,4 \%)$

$28(93,3 \%)$

(13) Meil tuleb selle ülesande lópetada.

$\begin{array}{llll}\text { NOM } & \text { GEN } & \text { GEN } & \text { PART } \\ \text { see ülesanne } & \text { selle ülesande } & \text { selle ülesande + ära } & \text { seda ülesannet } \\ \text { vene: } 12(41,4 \%) & 6(20,7 \%) & 2(6,9 \%) & 9(31 \%) \\ \text { eesti: } 30(100 \%) & 0 & 0 & 0\end{array}$

(14) Mul on unistus veel prantsuse keele ära öppida.

$\begin{array}{llll}\text { NOM keel } & \text { GEN keele } & \text { PART keelt } & \text { muu } \\ \text { vene: } 7(24,1 \%) & 12(41,4 \%) & 9(31,1 \%) & \begin{array}{l}1(3,4 \%) \text { (Ma unistan } \\ \text { prantsuse keele ---) } \\ \end{array} \\ \text { eesti: } 26(86,7 \%) & 4(13,3 \%) & 0 & 0\end{array}$

Näide (10) on eesti rühma hinnangul partitiivi eeldav kontekst. Vene rühm on enamuses aktsepteerinud genitiivset sihitist, mida võib seletada verbist lähtumise strateegiaga: verb on lihtminevikus ja väljendab juba lõpetatud tegevust. Tuleb tõdeda, et sihtkeelepärase tulemuse saavutamiseks peaksid õppijad lause põhiverbile toetumise kõrval suutma arvestada ka objektnoomeni eripära. Teoreetiliselt on olemas ka võimalus, et mõned L2-kõnelejad on näite (10) sihitist enesehinnangu partitiivivormiks pidanud, kuid kõrgtasemel eesti keelt valdavate eesti keele eriala üliõpilaste puhul on morfoloogiaviga siiski vähetõenäoline ning võib arvata, et lause parandamata jätnud õppijad on õigeks pidanud just genitiivivormi.

Impersonaalse öeldisverbiga näide (11) illustreerib kontekste, milles grammatikareeglite kohaselt genitiivobjekti tarvitamine võimalik ei ole ning kus õppijate introspektsiooni põhjal võib keeleõppijatelt verbi morfoloogilisele vormile toetumise põhjal eeldada ka partitiivi kontekstides nominatiivobjekti üldistamist. Suurem osa vene rühma vastajatest ongi nominatiivset sihitist õigeks pidanud, ühel juhul on peetud vajalikuks lisada nominatiivsele objektile resultatiivne laiend ära. Emakeelekõnelejate hinnangul on siin siiski tegemist partitiivi eeldava kontekstiga, kuigi 
neli eesti üliõpilast on tõenäoliselt tegevuse resultatiivsusest lähtudes aktsepteerinud ka nominatiivset sihitist.

Näites (12) on lause põhiverb eitav ning tingib seetõttu partitiivobjekti. Suur osa vene rühmast (ja ka kaks eesti üliõpilast) ei ole seda ilmselt märganud, jättes sihitise käände lauses muutmata. Vormihomonüümia tõttu pole võimalik üheselt määratleda, kas lauset õigeks pidanud teise keele kõnelejad on silmas pidanud nominatiiv- või hoopis genitiivobjekti, õppijate introspektsiooni käsitlevas uurimuses sisalduva sama lause analüüsi põhjal võib mõlema käände valikut võimalikuks pidada ning täissihitise valikut on informandid ise põhjendanud sihitisfraasis sisalduva täiendi terve olemasoluga (vt Pool 2006a) ${ }^{6}$. Grammatikareeglite kohaselt oleks vastavas jaatavas lauses täissihitisena võimalik ainult nominatiivi tarvitamine. Valikvastustega ülesande eitavate lausetega (4) ja (5) võrreldes on näha, et õppijatel on terviklikus lauses raskem eitust märgata ja eitavale verbivormile toetudes reeglipärast sihitisekäänet kasutada

Laused (13) ja (14) esindavad kontekste, milles $d a$-infintiivi laiendava täissihitise käändena on reeglipäraselt võimalik kasutada ainult nominatiivi, mis on olnud ka eesti üliõpilaste peamine valik. Väike varieerumine tuleb eesti rühma vastustes esile lauses (14), milles neli vastajat on lauses Mul on unistus veel prantsuse keele ära óppida sisalduvat genitiivset sihitist õigeks pidanud. Seesugustes resultatiivsetes konstruktsioonides genitiivi kui primaarse täissihitise käände kasutamine on tegelikult teise keele kõnelejatele iseloomulik valik (seda varianti pakkusid ka 12 L2-kõnelejat). Eesti vastajaid võib siin olla mõjutanud resultatiivse adverbi ära olemasolu või ka ülesandetüüp - terviklikus lauses ei pruugita kõiki detaile märgata. Valikvastustega ülesande sarnase konstruktsiooniga lauses (6), milles $d a$-infinitiiv talitleb samuti atribuudina, ei ole ükski eesti rühma vastajatest genitiivobjekti valinud, ühe partitiivijuhuga pakkusid kõik eesti vastajad varianti Olga läks raamatukokku kavatsusega referaat lópetada. Valikvastustega ülesanne on keele produtseerimisele lähedasem kui terviklausete korrektsuse hindamine ning tähelepanu

\footnotetext{
6 Sihitise vormihomonüümiast tulenevate õppijakeele analüüsiprobleemide kohta põhjalikumalt vt Pool 2006b.
} 
hajumisest tingitud juhuslikke valikuid tehakse harva. Vigade parandamise ülesandes on tähelepanematusest tulenevad ebatäpsused tavalisemad ning kuna sarnase struktuuriga lauses (6) eesti rühmal sarnaseid eksimusi ei olnud, on genitiivi aktsepteerinud eesti üliõpilaste grammatikateadmiste lünk vähetõenäoline. Vene rühma vastused erinevad neis lausetes tavapäraselt partitiivobjekti ületarvituse poolest, samas annab rohke täissihitise valik (sh sihtkeelepärane nominatiivobjekti tarvitamine) infot vaadeldava informandirühma eksplitsiitsetest keeleteadmistest ja oskusest neid teadmisi rakendada. Nii lauses (13) kui ka (14) on õppijatel täissihitise valimisel olnud võimalik toetuda sihitise põhisõnaks oleva verbi sisulisele resultatiivsusele.

\subsubsection{Sihitis partitiivverbi laiendina}

(15) Kuulsin reisikaaslaselt üks huvitav lugu.

NOM

üks huvitav lugu

vene: 0

eesti: 0

\section{GEN} ühe huvitava loo

$21(72,4 \%)$

$17(56,7 \%)$
PART

üht huvitavat lugu

$8(27,6 \%)$

$13(43,3 \%)$

(16) “Pange mu sõnad tähele!" ütles õpetaja.

NOM sõnad

vene: $23(79,3 \%)$

eesti: $1(3,3 \%)$
PART sõnu

$5(17,3 \%)$

$29(96,7 \%)$

\section{muu}

$1(3,4 \%)$ (Pöörake tähelepanu sellele, mida ma räägin.)

0

Lausete (15) ja (16) öeldisverbe kuulma ja tähele panema on L2-rühmale keeleõpetuses tutvustatud partitiiviverbidena. See sisendkeelest saadud info ei ole nendes testilausetes objekti käändevalikul siiski määravaks osutunud. Lause (15) tulemused on huvitavad selle poolest, et kõik nii eesti kui ka vene rühma vastajad on nominatiivset sihitist $\ddot{u} k s$ huvitav lugu valeks pidanud, kuid erinevalt valikvastustega ülesande sarnasest lausest (8), milles kõik eesti informandid on kuulma-verbi laiendiks valinud partitiivobjekti üht huvitavat ettekannet, on siinses ülesandes üle poole eesti vastajatest eelistanud genitiivobjekti. Kahe ülesande sarnase 
ülesehitusega lauseid võrreldes tuleb tõdeda, et lause Kuulsin hiljuti ühe huvitava ettekande tundus eesti vastajatele sobimatu valikuna (vaid üks vastaja valis selle partitiivi kõrvale paralleelvariandiks), kuid Kuulsin reisikaaslaselt ühe huvitava loo oli paljude arvates õige lause. Samas on mõlemal juhul tegemist piiritletud objektiga ning ka piiritletud tegevusega (piiritlejateks on mõlemas sihitisfraasis arvsõnaline täiend üks ning lausetes vastavalt määrused hiljuti ja reisikaaslaselt). L2-kõnelejad on lause (15) puhul täissihitist valides saanud toetuda lõpetatud tegevust väljendavale minevikulisele verbivormile (ilmselt samadel kaalutlustel on paljud õppijad valinud genitiivi ka lauses (8)).

Lause (16) öeldisverb tähele panema on õppijatele sisendkeelest kindlasti tuttav, kuid verbi kuulumisest partitiivverbide hulka on määravamaks osutunud tegusõna morfoloogiline vorm - käskivas kõneviisis öeldisverbiga (nagu ka umbisikulises tegumoes verbiga) seostab vaadeldav õppijarühm peamiselt nominatiivobjekti, mis siin ei vii sihtkeelepärase tulemuseni. Verbi vormilisele küljele toetumise strateegia tuleb esile õppijate introspektsioonis ning on hästi jälgitav selle lause rohkes nominatiivobjekti tarvituses.

\section{Kokkuvõtteks}

Artiklis käsitletud uurimuse vene emakeelega informandid on eesti keele eriala üliõpilastest kõrgtasemel eesti keele kõnelejatena väga hea eesti keele oskusega. Asjaolu, et nende objektitarvitus siiski suures osas eestlaste omast erineb, annab tunnistust sellest, et täis- ja osasihitise kasutust võib kahtlemata pidada keeleõppijate jaoks üheks kõige raskemini omandatavaks eesti keele grammatika osaks, mis edasijõudnud teise keele kõnelejaid emakeelekõnelejatest eristab. Vaadeldud informandirühm toetub introspektiivsete andmete kohaselt sihitise käände kasutamisel peamiselt lause põhiverbi vormilistele ja semantilistele omadustele ning verbile toetumist võib pidada õppijate strateegiaks.

Verbi vormilisele küljele toetumine andis häid tulemusi eitava öeldisverbiga lausetes, kus vene üliõpilaste valikud olid valikvastus- 
tega ülesandes eestlastega väga sarnased. Grammatikareeglite kohaselt laiendab eitavat verbivormi partitiivobjekt, ning isegi vormilt eitava, ka täissihitist võimaldava kahtlusküsimuse korral langesid teise keele kõnelejate valikud eestlaste omadega suures osas kokku. Vigade parandamise ülesande eitavas lauses esines käände valiku varieerumist nii vene kui ka eesti rühmal, mis võib tuleneda ka ülesandetüübist - terviklikes lausetes võib mõni grammatiline detail ka märkamata jääda.

Vaadeldud õppijarühma metalingvistiliste teadmiste kohaselt kuulub umbisikulise ja käskivas kõneviisis verbi juurde tavaliselt nominatiivne sihitis. Õppijate soov toetuda verbi morfoloogilisele vormile viis nimetatud juhtudel sihtkeelepärase tulemuseni nendes testülesannete lausetes, mis eeldasid täissihitise kasutamist. Imperatiivse ja impersonaalse partitiivverbi laiendiks valisid L2-kõnelejad samuti sageli nominatiivobjekti, mis annab tunnistust sellest, et verbi vormi peetakse sisulisest küljest olulisemaks sihitise käändevaliku kriteeriumiks. Verbi sisulisele resultatiivsusele toetumine paistab silma juhtudel, mil keerulistes nominatiivset täissihitist eeldavates kontekstides valitakse kas sihtkeelepärane nominatiiv või siis genitiiv kui primaarne täissihitise kääne. Vene rühma eristab eesti vastajatest ka sagedane partitiivobjekti ületarvitus täissihitise kontekstides.

\section{Tänusõnad}

Artikli valmimist on toetanud Haridus- ja Teadusministeeriumi riiklik programm "Eesti keel ja kultuurimälu" ning sihtfinantseeritav teadusteema SF0180056s08. Tänan anonüümseid retsensente asjatundlike nõuannete ja kommentaaride eest.

\section{Lühendid}

$\begin{array}{ll}\text { GEN } & \text { genitiiv } \\ \text { NOM } & \text { nominatiiv } \\ \text { PART } & \text { partitiiv }\end{array}$




\section{Kirjandus}

Abrahamsson, Niclas, Kenneth Hyltenstam 2009. Age of onset and nativelikeness in a second language: Listener perception versus linguistic scrutiny. - Language Learning 59 (2), 249-306. doi:10.1111/j.1467-9922.2009.00507.x

Argus, Reili 2009. Psühholingvistiline katse eesti keele objekti käändevahelduse omandamise uurimise meetodina. - Emakeele Seltsi aastaraamat 54, 22-42.

Bley-Vroman, Robert 1989. What is the logical problem of foreign language learning? - S. M. Gass, J. Schachter (Eds.). Linguistic Perspectives on Second Language Acquisition. Cambridge: Cambridge University Press, 41-68.

Bley-Vroman, Robert 1990. The logical problem of foreign language learning. Linguistic Analysis 20 (1-2), 3-49.

Ehala, Martin 2009. Keelekontakti mõju eesti sihitiskäänete kasutamisele. - Keel ja Kirjandus 3, 182-204.

EKG = Erelt, Mati, Reet Kasik, Helle Metslang, Henno Rajandi, Kristiina Ross, Henn Saari, KajaTael, Silvi Vare 1993. Eesti keele grammatika II. Süntaks. Lisa: kiri. Tallinn: Keele ja Kirjanduse Instituut.

Ellis, Rod 1990. Understanding Second Language Acquisition. Sixth impression. Oxford University Press.

Ellis, Rod, Gary Barkhuizen 2005. Analyzing Learner Language. Oxford: Oxford University Press.

Erelt, Mati 2000. Sihitis. - Keelenõuanne soovitab 2. Tallinn: Eesti Keele Sihtasutus, 91-98.

Firth, Alan, Johannes Wagner 1997. On discourse, communication, and (some) fundamental concepts in SLA research. - The Modern Language Journal 81, iii, 285-300.

Gass, Susan M. 2005. Input and interaction. - Catherine J. Doughty, Michael H. Long (Eds.). The Handbook of Second Language Acquisition. Malden: Blackwell, 224-255.

Han, ZhaoHong 2003. Fossilisation: From simplicity to complexity. - International Journal of Bilingual Education and Bilingualism 6 (2), 95-128.

Han, ZhaoHong 2004. Fossilization: Five central issues. - International Journal of Applied Linguistics 14 (2), 212-242. doi:10.1111/j.1473-4192. 2004.00060.x

Hyltenstam, Kenneth, Niclas Abrahamsson 2000. Who can become native-like in a second language? All, some, or none? - Studia Linguistica 54 (2), 150-166. doi:10.1111/1467-9582.00056 
Klaas, Birute 1999. Dependence of the object case on the semantics of the verb in Estonian, Finnish, and Lithuanian. - Mati Erelt (Ed.). Estonian: Typological Studies III. Tartu Ülikooli eesti keele õppetooli toimetised 11. Tartu: Tartu Ülikool, 47-83.

Krall, Ingrid 2008. Eesti keele käändevormide moodustamise ja kasutamisega seotud probleeme vene üliõpilaste kirjalikes töödes. - Pille Eslon (Toim.). Õppijakeele analüüs: võimalused, probleemid, vajadused. Tallinna Ülikooli eesti filoloogia osakonna toimetised 10. Tallinn: TLÜ Kirjastus, 137-176.

Lakshmanan, Usha, Larry Selinker 2001. Analyzing interlanguage: How do we know what learners know? - Second Language Research 17 (4), 393-420. doi:10.1177/026765830101700406

Lehiste, Ilse, Juta Kitching 1998. Sihitise käänete kasutamisest väliseestlaste poolt. Liina Lindström (Toim.). Väliseestlaste keelest. Tartu Ülikooli eesti keele õppetooli toimetised 9. Tartu: Tartu Ülikooli Kirjastus, 67-75.

Metslang, Helle, Ingrid Krall, Renate Pajusalu, Kristi Saarso, Elle Sõrmus, Silvi Vare 2003. Keelehärm. Eesti keele probleemseid piirkondi. Tallinn: TPÜ Kirjastus.

Pool, Raili 2005. Täis- ja osasihitis kõrgtasemel eesti keelt teise keelena kõnelejate kirjalikus keelekasutuses. - Raili Pool (Toim.). Teine keel. Uurimusi eesti keele kui teise keele omandamisest. Tartu Ülikooli eesti keele (võõrkeelena) õppetooli toimetised 5. Tartu: Tartu Ülikooli Kirjastus, 8-74.

Pool, Raili 2006a. Täis- ja osasihitise kasutamisest eesti keelt teise keelena õppijate pilgu läbi. - Eesti Rakenduslingvistika Ühingu aastaraamat 2, 185-202.

Pool, Raili 2006b. Sihitise vormihomonüümia - keeleuurija probleem, keeleõppija tugi. - Külvi Pruuli, Annekatrin Kaivapalu (Toim.). Lähivertailuja 17. Jyväskylä Studies in Humanities 53. Jyväskylä: Jyväskylän yliopisto, 85-101.

Pool, Raili 2007a. Täis- ja osasihitise omandamise ning markeerituse seosest. Keel ja Kirjandus 1, 35-50.

Pool, Raili 2007b. Keeleõppijate vältimisstrateegiatest eesti keele täis- ja osasihitise näitel. - Eesti Rakenduslingvistika Ühingu aastaraamat 3, 235-252.

Pool, Raili, Elle Vaimann 2005. Vead kõrgtasemel eesti keele kõnelejate kirjalikus keelekasutuses. - Eesti Rakenduslingvistika Ühingu aastaraamat 1, 115138.

Raag, Raimo 1985. The direct object in Swedish Estonian. - Eesti Teadusliku Seltsi Rootsis Aastaraamat. Annales Societatis Litterarum Estonicae in Svecia. IX 1980-1984. Stockholm, 201-211.

Rätsep, Huno 1978. Eesti keele lihtlausete tüübid. Tallinn: Valgus. 
Selinker, Larry 1972. Interlanguage. - International Review of Applied Linguistics in Language Teaching 10 (2), 209-231. doi:10.1515/iral.1972.10.1-4.209

Siitonen, Kirsti 1999. Agenttiä etsimässä. $U$-verbijohdokset edistyneen suomenoppijan ongelmana. Turun yliopiston suomalaisen ja yleisen kielitieteen laitoksen julkaisuja 63. Turku.

Tarone, Elaine 1983. On the variability of interlanguage systems. - Applied Linguistics 4 (2), 43-163. doi:10.1093/applin/4.2.142

Torn, Reeli 2004. Sihitisekäänete ja tulevikuvormide kasutamine kolme eesti-inglise kakskeelse lapse eesti keeles. - Birute Klaas, Silvi Tenjes (Toim.). Emakeel ja teised keeled IV. Tartu Ülikooli eesti keele (võõrkeelena) õppetooli toimetised 3. Tartu: Tartu Ülikooli Kirjastus, 177-191.

Verschik, Anna 2004. Mõnda vahekeelest ja kontrastiivsest analüüsist. - Mart Rannut, Marju Kõivupuu, Tiit Päeva (Toim.). Eesti keel: võõrkeelest teiseks keeleks. TPÜ eesti filoloogia osakonna toimetised 1. Tallinn: TPÜ Kirjastus, $132-144$.

\section{Raili Pool}

Tartu Ülikooli eesti ja üldkeeleteaduse instituut

Ülikooli 18

50090 Tartu, Estonia

raili.pool@ut.ee 


\title{
The use of total and partial objects by university students who are native speakers of Russian or Estonian
}

\author{
RAILI POOL \\ University of Tartu
}

The article compares the use of total and partial objects by L2 and L1 speakers of Estonian. For the purposes of the article, L2 speakers of Estonian are native speakers of Russian who are pursuing a programme of studies in Estonian as a foreign language and who possess an advanced knowledge of Estonian. They are fully conversant with Estonian grammar and the usage rules of objects in Estonian. L1 speakers of Estonian are students of various specialities from the universities in Tartu and in Tallinn. The article analyses answers given by the participants in the multiple choice test and grammaticality judgement test. The choices made by L2 and L1 learners of Estonian in the use of total and partial objects showed considerable variation, which means that this aspect of grammar is one of the most difficult ones for learners of Estonian. The choices made by the Russian-speaking students differed from those of Estonian-speaking students in three aspects: 1) they tended to overuse partial objects in the context of total objects; 2) they made mistakes in selecting the object case of a total object; 3 ) they used total objects in certain contexts requiring partitive ones. The two groups used objects similarly in negative sentences and with certain partitive verbs.

Keywords: language learning; second language acquisition; native speaker; non-native speaker; object cases; aspectual verbs; partitive verbs; introspection; Russian; Estonian 